\title{
PENGARUH MEDIA PEMBELAJARAN BERBASIS CISCO IT ESSENSIALS VIRTUAL DESKTOP DAN MOTIVASI BELAJAR DALAM MENINGKATKAN HASIL BELAJAR MATA PELAJARAN PERAKITAN KOMPUTER DI SMK AL FURQON MRANGGEN DEMAK
}

\author{
Mohammad Ali Mahbub \\ SMK Al Furqon Demak \\ *mahbubali106@gmail.com
}

Diterima: Nopember 2018. Disetujui: Desember 2018. Dipublikasikan: Desember 2018

ABSTRAK

Penggunaan media dalam proses pembelajaran merupakan hal yang sangat penting, yang nantinya akan sangat saling mempengaruhi dengan komponen- kompenen yang ada dalam sistem belajar. Penelitian ini merupakan salah satu upaya untuk mendorong warga sekolah dalam mengembangkan dan memanfaatkan TIK, khususnya media IT Essentials Virtual Desktop dalam proses pembelajaran. Melihat kondisi tersebut, maka penulis tertarik untuk melakukan penelitian tentang Pengaruh Media Pembelajaran Berbasis Cisco It Essensials Virtual Desktop Dan Motivasi Belajar Dalam Meningkatkan Hasil Belajar Mata Pelajaran Perakitan Komputer Di Smk Al Furqon Mranggen Demak. 6. Berdasarkan hasil analisis nilai F sebesar 9,590, sedangkan nilai signifikansi F sebesar 0,000. Dengan menggunakan DFI $=2$ dan DF (degree of freedom) sebesar 53 (56 - 2 1) di peroleh nilai $F$ sebesar 3,1716 dari hasil tersebut nilai $F$ hitung lebih besar 9,590 dan nilai signifikansi sebesar 0,000 lebih rendah dari 0,05 ( $\alpha=5 \%)$ yang menunjukkan Ho ditolak dan Ha diterima, sehingga hipotesis yang menyatakan "ada pengaruh positif penggunaan media pembelajaran cisco (X1) terhadap hasil belajar siswa kelas X dan XI TKJ SMK AL FURQON Mranggen Demak" dapat diterima.

Kata kunci: media pembelajaran, pembelajaran cisso, motivasi belajar.

\begin{abstract}
The use of media in the learning process is very important, which later will greatly affect each other's components in the learning system. This research is an effort to encourage school citizens to develop and utilize ICT, especially the IT media Essentials Virtual Desktop in the learning process. Seeing these conditions, the authors are interested in conducting research on the Effect of Cisco It Essensials Virtual Desktop Based Learning Media and Learning Motivation in Improving Learning Outcomes in Computer Assembly Subjects at Al Furqon Senior High School Mranggen Demak. 6. Based on the results of the analysis the value of $F$ is 9.590, while the significance value of $F$ is 0,000. By using DFI $=2$ and DF (degree of freedom) of 53 (56 - 2 - 1) the $F$ value is 3.1716 from the results of the calculated $F$ value of 9.590 and the significance value of 0.000 lower than $0.05(\alpha=5 \%)$ which shows that Ho is rejected and Ha is accepted, so the hypothesis which states "there is a positive influence on the use of Cisco learning media (XI) on the learning outcomes of class X and XI of Mranggen Demak AL FURQON Vocational School" is acceptable.
\end{abstract}

Keywords: learning media, cisso learning, learning motivation.

\section{PENDAHULUAN}

Siswa SMK AL FURQON Mranggen

Demak berasal dari Sekolah Menengah Pertama (SMP) yang berbeda dan sebagian diantaranya berasal dari SMP yang memiliki fasilitas yang kurang lengkap, kondisi ini mengakibatkan pemahaman siswa tentang komputer masih kurang, latar belakang ekonomi orang tua siswa kebanyakan berasal dari keluarga ekonomi menengah ke bawah.

Mata Pelajaran Perakitan Komputer merupakan salah satu Mata Pelajaran produktif yang ada di Sekolah Menengah

Meningkatkan Hasil Belajar Mata Pelajaran Perakitan Komputer Di SMK Al Furqon Mranggen Demak | 126 
Kejuruan program keahlian Teknik Komputer dan Jaringan. Mata Pelajaran Perakitan Komputer juga merupakan bahasan paling dasar dalam pemahaman mengenai komputer. Tercapainya tujuan pendidikan tidak terlepas dari adanya pengembangan di bidang pendidikan antara lain meliputi proses pembelajaran, media pembelajaran dan pengelolaan sarana dan prasarana.

Berdasarkan fakta dilapangan bahwa untuk Mata Pelajaran Perakitan Komputer masih terdapat nilai yang di bawah standar KKM (Kriteria Ketuntasan Minimum), jumlah siswa yang telah mencapai nilai standar KKM masih di bawah $65 \%$ dalam satu kelas. Kondisi tersebut menunjukkan bahwa hasil belajar siswa masih kurang optimal dan perlu perbaikan.

Kemudian dilakukan wawancara dengan guru pelajaran perakitan komputer, hal ini disebabkan oleh kurangnya penguasaan siswa dalam konsep perakitan personal komputer dan keterbatasan perangkat praktik yang digunakan serta kurangnya penggunaan media pembelajaran. Penggunaan media pembelajaran interaktif diharapkan dapat meningkatkan kualitas proses belajar mengajar yang memberi pengaruh pada peningkatan kualitas hasil belajar peserta didik.

Media interaktif telah banyak dibuat dari kalangan individu maupun perusahaan. Salah satu perusahaan yang membuat media interaktif adalah Perusahan Cisco. Perusahaan tersebut membuat aplikasi Cisco IT Essentials Virtual Desktop sebagai media interaktif untuk Mata Pelajaran perakitan komputer. Aplikasi ini menjelaskan komponen hardware secara detail dan menumenu yang mendukung, sehingga dapat digunakan sebagai media pembelajaran perakitan komputer di sekolah. Program virtual ini mirip dengan hardware aslinya. Hal tersebut diharapkan, siswa bisa belajar layaknya merakit komputer secara nyata. Oleh karena itu, media pembelajaran seperti ini diharapkan meningkatkan proses belajar siswa yang efektif pada Mata Pelajaran perakitan komputer.

Menurut salah satu guru pengampu Mata Pelajaran perakitan komputer SMK AL FURQON menyampaikan bahwa berkaitan dengan itu perlu dilakukan tindakan nyata yaitu melakukan inovasi dalam pembelajaran, inovasi tersebut bertujuan untuk membuat kegiatan belajar mengajar lebih baik dan lebih dapat dipahami. Salah satu solusi untuk memecahkan permasalahan tersebut adalah sebelum melakukan praktik langsung menggunakan perangkat nyata, para siswa dicoba menggunakan perangkat lunak IT Essensial Virtual Desktop Cisco sebagai sarana simulasi dalam perakitan computer, sebagai media alternatif untuk meningkatkan keaktifan dan inovatif proses belajar siswa. Sebab jika menggunakan perangkat nyata dibutuhkan alat yang cukup banyak dan biaya yang cukup mahal untuk membelinya, agar praktikum bisa berjalan dengan lancar.

Pencapaian hasil belajar dari suatu pembelajaran tidak akan terlepas dari sebuah proses pembelajaran yang dialaminya, sebab hasil belajar merupakan tolak ukur pemahaman siswa pada proses pembelajaran. Pencapaian tujuan belajar atau pemahaman siswa yang maksimal di butuhkan proses pembelajaran yang optimal juga. pembelajaran menggunakan media dapat mendukung pembelajaran yang lebih interaktif, menyenangkan dan pemahaman siswa terhadap materi yang di sampaikan guru untuk lebih maksimal. masih adanya guru yang kurang memanfaatkan berbagai media secara optimal dalam pembelajaran membuat pembelajaran terlihat monoton dan masih banyak sekolah yang tidak mempunyai fasilitas yang memadai untuk pembelajaran TIK yang baik membuat guru sulit menyampaikan materi ajar dengan baik kepada siswa. 
Selain media pembelajaran, tingkat motivasi belajar siswa juga berperan penting dalam pencapaian prestasi belajar siswa. Motivasi dalam proses pembelajaran merupakan kekuatan mental yang berupa keinginan, perhatian, dan kemauan atau citacita yang dapat menggiatkan aktifitas belajar siswa sebagai pendorong untuk tercapainya prestasi belajar yang diharapkan. Berdasarkan pengamatan pada saat di sekolahan masih banyak siswa yang sering acuh dan tidak memperhatikan pada saat dijelaskan, mengobrol dengan teman disampingnya, bermain handphone serta masih banyak siswa yang keluar kelas untuk mengikuti acara ekstrakulikuler disaat jam pelajaran berlangsung.

Keterbatasan perangkat komputer yang banyak ditemukan disekolah-sekolah adalah salah satu hambatan untuk terciptanya proses pembelajaran yang baik, salah satu sekolah yang saya temui di lapangan adalah Sekolah Menengah Kejuruan AL FURQON Mranggen dengan program keahlian jaringan, yang harusnya mempunyai banyak perangkat komputer dalam setiap proses pembelajarannya hanya mempunyai beberapa perangkat komputer saja. Proses pembelajaran Merakit Personal Komputer hanya mampu memperkenalkan komponenkomponennya saja, karena tidak bisa merakit secara keseluruhan dengan utuh. Komputer yang digunakan dalam proses pembelajaran merakit ini juga digunakan dalam proses pembelajaran lainnya sehingga akan menimbulkan rawannya kerusakan yang terjadi pada komputer. Minimnya perangkat komputer yang ada membuat kegiatan pembelajaran kurang maksimal untuk mencapai tujuan pembelajaran.

Penelitian ini merupakan salah satu upaya untuk mendorong warga sekolah dalam mengembangkan dan memanfaatkan TIK, khususnya media IT Essentials Virtual Desktop dalam proses pembelajaran. Melihat kondisi tersebut, maka penulis tertarik untuk melakukan penelitian tentang "PENGARUH MEDIA PEMBELAJARAN BERBASIS CISCO IT ESSENSIALS VIRTUAL DESKTOP DAN MOTIVASI BELAJAR DALAM MENINGKATKAN HASIL BELAJAR MATA PELAJARAN PERAKITAN KOMPUTER DI SMK AL FURQON MRANGGEN DEMAK”.

\section{METODE PENELITIAN Desain Penelitian}

Penelitian ini termasuk penelitian kuantitatif. Penelitian ini tidak melakukan treatmen, melainkan meneliti masalah atau peristiwa yang telah terjadi dan tidak melakukan kontrol terhadap variabel penelitian, melainkan melihat variabel sebagaimana mestinya.

Jenis penelitian ini merupakan penelitian Ex Post Facto, seperti yang dikemukakan Sugiyono (2004:7) yaitu penelitian yang dilakukan untuk meneliti peristiwa yang telah terjadi dan kemudian meruntut kebelakang untuk mengetahui faktor-faktor yang menimbulkan kejadian tersebut. Pendekatan yang digunakan dalam penelitian ini adalah pendekatan kuantitatif. Pendekatan kuantitatif yaitu semua gejala yang diamati diwujudkan dalam bentuk angka dan menggunakan analisis statistik. Penelitian kuantitatif digunakan untuk mengukur semua variabel bebas dan variabel terikat.

Penelitian Ex Post Facto secara metodis merupakan penelitian yang juga menguji hipotesis tetapi tidak memberikan perlakuan- perlakuan tertentu karena sesuatu sebab kurang etis untuk memberikan perlakuan atau memberikan manipulasi. Biasanya karena alasan etika manusiawi, atau gejala atau peristiwa tersebut sudah terjadi dan ingin menelusuri faktor- faktor penyebabnya atau hal-hal yang mempengaruhinya.

Sehubungan dengan ini maka yang akan dikaji lebih jauh dalam sebuah

Pengaruh Media Pembelajaran Berbasis Cisco IT Essensials Virtual Desktop Dan Motivasi Belajar Dalam Meningkatkan Hasil Belajar Mata Pelajaran Perakitan Komputer Di SMK Al Furqon Mranggen Demak | 128 
penelitian adalah meneliti adanya pengaruh Media Pembelajaran Berbasis Cisco IT Essensials Virtual Desktop dalam meningkatkan motivasi dan hasil belajar Mata Pelajaran Perakitan Komputer di SMK AL FURQON Mranggen Demak Tahun Ajaran 2017/2018.

\section{Subyek Penelitian}

Penelitian ini dilaksanakan di SMK AL FURQON Mranggen yang beralamat di Jalan Watunganten No. 123, Batursari Mranggen Demak.Waktu penelitian dilaksanakan pada bulan April s/d Juni 2018.

\section{Prosedur Pengumpulan data}

Teknik pengumpulan data yang digunakan dalam penelitian ini adalah melalui dokumentasi dan angket: (1) Pengumpulan Data Menggunakan Dokumentasi. Metode dokumentasi yaitu mencari data mengenai hal- hal atau variabel yang berupa catatan, transkip, buku, surat kabar, majalah, prasasti, notulen, rapat, lengger, agenda dan lain sebagainya (Arikunto, 2010: 206). Metode dokumentasi dalam penelitian ini digunakan untuk mengumpulkan identitas dan hasil belajar Perakitan Komputer siswa kelas X dan XI program keahlian Teknik Komputer dan Jaringan SMK AL FURQON Mranggen Demak Tahun Ajaran 2017/2018.

(2) Pengumpulan Data Menggunakan Angket. Menurut Sugiono (2010:199) teknik angket merupakan teknik pengumpulan data dengan memberikan beberapa seperangkat pertayaan atau pernyataan tertulis kepada responden untuk dijawab. Bentuk angket yang digunakan dalam penelitian ini adalah angket tertutup. Angket tertutup yang dimaksud merupakan angket yang disajikan dalam bentuk sedemikian rupa sehingga responden diminta untuk memilih salah satu jawaban yang sesuai dengan karakteristik dirinya dengan cara memberikan tanda tanda check $(\sqrt{ })$, responden tinggal memilih salah satu jawaban yang disediakan. Bobot jawaban dari pernyataan positif berkisar 1 sampai 4. Bobot jawaban dari pernyataan negatif berkisar 4 sampai 1 .

Langkah-langkah yang ditempuh dalam penyusunan angket dalam penelitian ini adalah sebagai berikut: (a) Merumuskan konsep dasar tertentu yang dijadikan pusat perhatian dalam lingkup masalah yang diteliti, (b) Menentukan variabel penelitian, (c) Menentukan indikator tiap variable. Angket dalam penelitian ini berupa angket hasil dari media pembelajaran $\left(\mathrm{X}_{1}\right)$, motivasi belajar $\left(\mathrm{X}_{2}\right)$, dan hasil belajar(Y).

\section{Instrumen Penelitian}

Instrumen merupakan alat bantu yang digunakan untuk mengumpulkan data. Penelitian ini menggunakan angket tertutup dimana jawaban sudah disediakan oleh peneliti sehingga respoden tinggal memilih. Angket ini menggunakan skala likert. Menurut Sugiyono (2010:134) skala likert digunakan untuk mengukur sikap atau pendapat seseorang atau sejumlah kelompok terhadap sebuah fenomena sosial dimana jawaban setiap butir instrument mempunyai gradasi dari sangat positif sampai sangat negatif. Pengisian angket ini dengan cara setiap responden harus memilih satu diantara 4 alternatif jawaban yang ada dari masingmasing butir, tidak ada jawaban benar atau salah, setiap jawaban mempunyai skor yang berbeda. Melalui skala Likert variabelvariabel yang akan diukur dijabarkan menjadi indikator indikator.

Untuk lebih jelas dapat dilihat pada:

Tabel 1. Skala Likert

\begin{tabular}{l|l|l|l|l}
\hline $\begin{array}{l}\text { Butir } \\
\text { pernyataan }\end{array}$ & $\begin{array}{l}\text { Sangat } \\
\text { Setuju } \\
(\text { SS })\end{array}$ & $\begin{array}{l}\text { Setuju } \\
(\text { S) }\end{array}$ & $\begin{array}{l}\text { Tidak } \\
\text { Setuju } \\
\text { (TS) }\end{array}$ & $\begin{array}{l}\text { Sangat } \\
\text { Tidak } \\
\text { Setuju } \\
\text { (STS) }\end{array}$ \\
\hline Positif & 4 & 3 & 2 & 1 \\
\hline Negatif & 1 & 2 & 3 & 4 \\
\hline
\end{tabular}

Pengaruh Media Pembelajaran Berbasis Cisco IT Essensials Virtual Desktop Dan Motivasi Belajar Dalam Meningkatkan Hasil Belajar Mata Pelajaran Perakitan Komputer Di SMK Al Furqon Mranggen Demak | 129 


\section{Uji Coba Instrumen}

Untuk menguji apakah instrumen yang digunakan sudah valid serta reliabel atau belum, maka perlu dilakukan uji coba instrumen kepada subyek diluar sampel. Hasil uji coba instrumen akan dianalisis untuk dikatahui tingkat validitas dan reliabilitasnya.

Uji coba instrumen dilakukan pada 20 responden dengan cara mengisi angket prakerin dan lingkungan keluarga serta angket minat berwirausaha kemudian data yang diperoleh selanjutnya diolah untuk mendapatkan data yang valid dan reliabel. Instrumen yang baik harus memenuhi dua persyaratan penting yaitu valid dan reliabel. (1) Validitas, Menurut Sugiyono (2010: 363) validitas adalah derajat ketepatan antara data yang terjadi pada obyek penelitian dengan data yang dapat dilaporkan oleh penelitian. Sebuah instrumen dikatakan valid apabila mampu mengukur apa yang diinginkan dan dapat mengungkapkan data dari variabel yang diteliti secara tepat. Instrumen yang valid berarti alat ukur yang digunakan untuk mendapatkan data itu valid, berarti instrumen tersebut dapat digunakan untuk mengukur apa yang hendak diukur (Sugiyono, 2010: 267).

Validitas sangat penting karena tanpa instrumen yang valid, data atau penelitian akan memberikan kesimpulan yang bias. Berdasarkan cara pengujiannya, penelitian ini merupakan jenis validitas internal. Validitas internal dicapai apabila terdapat kesesuaian antara bagian-bagian instrumen dengan instrumen secara keseluruhan.

Validitas dalam penelitian ini dilakukan dengan menggunakan sampel uji coba sebanyak 15 anak, yang diambil dari luar anggota sampel penelitian. Pengujian valditas dihitung dengan menggunakan bantuan program SPSS Versi 21.0. (2) Reliabilitas Angket, "Reliabilitas menunjuk pada satu pengertian bahwa sesuatu instrumen cukup dapat dipercaya untuk digunakan sebagai alat pengumpul data karena instrumen tersebut sudak baik" (Arikunto, 2010: 178).

Suatu instrumen dikatakan reliabel apabila instrumen yang digunakan beberapa kali untuk mengukur obyek yang sama, akan menghasilkan data yang sama. Pengujian reliabilitas instrumen dalam penelitian ini digunakan rumus Alpha Cronbach dengan $\alpha$ dinilai reliabel jika lebih besar dari 0,60 (Ghozali,2005). Perhitungan Uji realibilitas di sini digunakan program bantu Microsoft Excel 2007.

\section{Teknik Analisis Data}

(1) Analisis deskriptif

Analisis deskriptif dimaksud untuk mendapatkan gambaran bagaimana penyebaran hasil penelitian masing-masing variabel. Penilaian angket dengan menggunakan skala linkert dengan 4 katogori yang di dasarkan pada pengantar statistik pendidikan. Pedoman penilaian skor terhadap jawaban yang diberikan responden adalah sebagai berikut :

$\mathrm{Mi}+1,5 \mathrm{Sdi}$ s/d skor tertinggi = sangat baik

Mi s/d Mi + Sdi = baik

$\mathrm{Mi}-1,5 \mathrm{Sdi}$ s/d Mi = kurang baik

Skor terendah s/d Mi - 1,5 Sdi = tidak baik

(2) Uji Prasyaratan Analisis

Maksud uji persyaratan analisis untuk mengetahui apakah data penelitian yang dikumpulkan memenuhi syarat untuk dianalisiskan dengan statistik yang digunakan. Teknik statistik yang digunakan dalam penelitian ini adalah analisis sederhana. Pengguna analisis statistika tersebut diatas terlebih dahulu memenuhi persyaratan-persyaratan sebagai berikut: normalitas dan linieritas

(3) Uji Regresi

Pengaruh Media Pembelajaran Berbasis Cisco IT Essensials Virtual Desktop Dan Motivasi Belajar Dalam Meningkatkan Hasil Belajar Mata Pelajaran Perakitan Komputer Di SMK Al Furqon Mranggen Demak | 130 
Uji regresi meliputi: (a) Regresi Linier Sederhana, (b) Uji Hipotesis, (b) Koefisien Determinasi, (c) Uji Regresi Linier Sederhana

\section{HASIL DAN PEMBAHASAN}

\section{Penggunaan Media Pembelajaran Cisso}

Media Pembelajaran Cisco kelas X dan XI TKJ SMK AL FURQON Mranggen Demak menggambarkan bahwa dengan responden sebanyak 48, skor rata-rata (means) 48.3125 dengan Std.Error of mean tingkat kesalahan dari rata-rata 0.702 . Nilai maximum sebesar 57 dan nilai minimum 35 .

Distribusi Skoring Angket Penggunaan Media Cisco

Tabel 2 Deskriptif Frekuensi Variabel Media Cisco

\begin{tabular}{llll}
\hline Interval & Kriteria & Frekuensi & Presentase \\
\hline $49-60$ & $\begin{array}{l}\text { Sangat } \\
\text { Setuju }\end{array}$ & 26 & $54 \%$ \\
$37-48$ & Setuju & 22 & $46 \%$ \\
$26-36$ & $\begin{array}{l}\text { Tidak } \\
\text { Setuju }\end{array}$ & 0 & $0 \%$ \\
$15-25$ & $\begin{array}{l}\text { Sangat } \\
\text { Tidak } \\
\text { Setuju }\end{array}$ & 0 & $0 \%$ \\
& & 48 & $100 \%$
\end{tabular}

Berdasarkan gambar 1 menunjukan nilai tertinggi berada pada kriteria sangat setuju, yaitu $54 \%$ hasil tersebut menggambarkan bahwa mayoritas siswa kelas X dan XI TKJ SMK AL FURQON Mranggen Demak mempunyai persepsi sangat setuju terhadap penggunaan Media Pembelajaran Cisco. Sedangkan $46 \%$ siswa memiliki persepsi setuju terhadap penggunaan Media Pembelajaran Cisco.

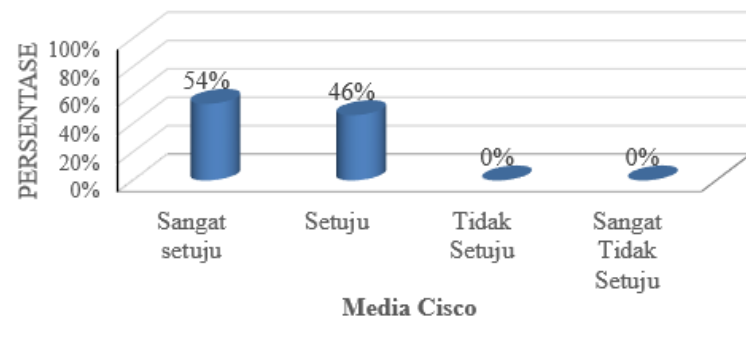

Gambar 1. Tanggapan Responden Terhadap Variabel Media Cisco $\left(\mathrm{X}_{1}\right)$

\section{Motivasi Belajar}

Variabel penggunaan Motivasi Belajar diungkap lewat angket penelitian dengan item nomor 1 (satu) sampai nomor 15 (lima belas). Untuk menentukan tinggi rendahnya variabel Motivasi Belajar digunakan 4 Kategori, yakni: sangat setuju, setuju, tidak setuju, sangat tidak setuju. Untuk Skor tertinggi $15 \times 4=60$ dan skor terendah $15 \times 1=15$ sehingga lebar interval dapat dihitung sebagai berikut :

Tabel 3. Deskriptif Frekuensi Variabel Motivasi Belajar

\begin{tabular}{clcc}
\hline Interval & Kriteria & Frekuensi & Preseentase \\
\hline $49-60$ & Sangat & 14 & $29 \%$ \\
& Setuju & & \\
$37-48$ & Setuju & 34 & $71 \%$ \\
$26-36$ & Tidak & 0 & $0 \%$ \\
& Setuju & & \\
$15-25$ & Sangat & 0 & $0 \%$ \\
& Tidak & & \\
& Setuju & & $100 \%$ \\
\hline \multicolumn{2}{c}{ Total } & 48 &
\end{tabular}

Berdasarkan gambar 4.3 diperoleh kriteria sangat setuju, yaitu $29 \%$ berjumlah 14 dan setuju $71 \%$ berjumlah 37 sehingga dapat disimpulkan bahwa minat belajar siswa dalam penggunaan media pembelajaran Cisco kelas $\mathrm{X}$ dan XI TKJ SMK AL FURQON Mranggen Demak adalah baik. Dari perhitungan diperoleh jumlah skor terendah 37 dan skor tertinggi 57 dengan rata-rata 46.4792.

Pengaruh Media Pembelajaran Berbasis Cisco IT Essensials Virtual Desktop Dan Motivasi Belajar Dalam Meningkatkan Hasil Belajar Mata Pelajaran Perakitan Komputer Di SMK Al Furqon Mranggen Demak | 131 


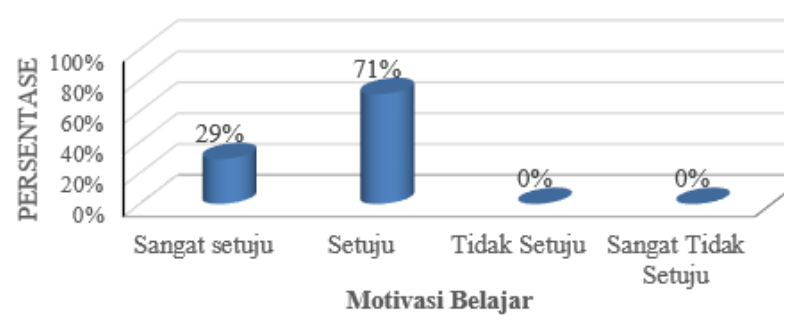

Gambar 2. Tanggapan Responden Terhadap Variabel Motivasi Belajar $\left(\mathrm{X}_{2}\right)$

\section{Hasil Belajar Siswa}

Variabel hasil belajar siswa diungkap lewat angket penelitian dengan item nomor 1 (satu) sampai nomor 15 (lima belas). Untuk menentukan tinggi rendahnya variabel hasil belajar siswa digunakan 4 Kategori, yakni : sangat setuju, setuju, tidak setuju, sangat tidak setuju. Untuk Skor tertinggi 15 x $4=60$ dan skor terendah 15 x $1=15$.

Tabel 4. Deskriptif Frekuensi Variabel Hasil Belajar

\begin{tabular}{llll}
\hline Interval & Kriteria & $\mathrm{N}$ & Preseentase \\
\hline $49-60$ & $\begin{array}{l}\text { Sangat } \\
\text { Setuju }\end{array}$ & 17 & $35 \%$ \\
$37-48$ & Setuju & 31 & $65 \%$ \\
$26-36$ & $\begin{array}{l}\text { Tidak } \\
\text { Setuju }\end{array}$ & 0 & $0 \%$ \\
$15-25$ & $\begin{array}{l}\text { Sangat } \\
\text { Tidak } \\
\text { Setuju }\end{array}$ & 0 & $0 \%$ \\
\hline Total & & 48 & $100 \%$ \\
\hline
\end{tabular}

Berdasarkan analisis data diperoleh kriteria Sangat Setuju (35\%) berjumlah 17 dan Setuju (65\%) sejumlah 31 sehingga dapat disimpulkan bahwa Hasil Belajar Siswa dalam pembelajaran di kelas $\mathrm{X}$ dan $\mathrm{XI}$ jurusan TKJ SMK AL FURQON Mranggen Demak adalah dalam kategori baik.

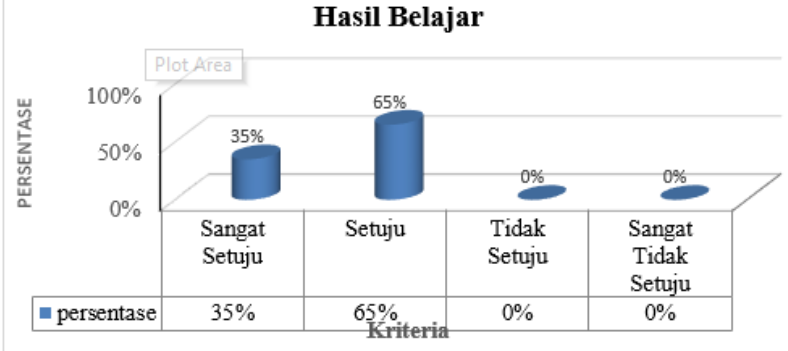

Gambar 3. Tanggapan Responden Terhadap Variabel Hasil Belajar (Y)

\section{PENNUTUP}

\section{Kesimpulan}

Berdasarkan hasil analisis data Pengaruh Penggunaan Media Pembelajaran Cisco dan Motivasi Belajar terhadap Hasil Belajar siswa Kelas X dan XI Program Keahlian Teknik Komputer dan Jaringan (TKJ) SMK AL FURQON Mranggen Demak Tahun Pelajaran 2017/2018 dapat disimpulkan sebagai berikut :

(1) Penggunaan Media Pembelajaran Cisco di kelas X dan XI jurusan TKJ SMK AL FURQON Mranggen Demak adalah dalam kategori sangat baik. Hal ini ditunjukan data Kriteria Sangat Setuju (54\%) berjumlah 26, Setuju (46\%) sejumlah 22 siswa. (2) Motivasi Belajar di kelas X dan XI jurusan TKJ SMK AL FURQON Mranggen Demak adalah dalam kategori baik. Hal ini berdasarkan analisis data diperoleh kriteria Sangat Setuju (29\%) berjumlah 14 dan Setuju (71\%) sejumlah 34 Siswa. (3)Hasil Belajar di kelas $X$ dan XI jurusan TKJ SMK AL FURQON Mranggen Demak adalah dalam kategori baik. Berdasarkan analisis data diperoleh kriteria sangat setuju (35\%) berjumlah 17 dan setuju (65\%) berjumlah 31 siswa, dengan skor terendah 38 dan skor tertinggi 59 dengan rata-rata 47.9375. (4) Penggunaan Media Pembelajaran Cisco berpengaruh terhadap Hasil Belajar Siswa, hal ini ditunjukkan dari hasil uji $\mathrm{t}=0,002$ lebih rendah dari $0,05(\alpha=5 \%)$ yang menunjukkan Ho ditolak Ha diterima, 
sehingga hipotesis yang menyatakan "ada pengaruh positif penggunaan Media Pembelajaran Cisco terhadap Hasil Belajar siswa kelas $\mathrm{X}$ dan XI TKJ SMK AL FURQON Mranggen Demak" dapat diterima. Sedangkan koefisien determinansi penggunaan Media Pembelajaran Cisco terhadap Hasil Belajar (Y) besarnya adjusted R Square sebesar 0,190 hal ini berarti 19,0\%, sedangkan sisanya $(100 \%-19,0 \%)=81 \%)$ dijelaskan oleh sebab-sebab lain. (5) Motivasi Belajar berpengaruh terhadap Hasil Belajar Siswa, hal ini ditunjukkan dari hasil uji $\mathrm{t}=0,000$ lebih rendah dari 0,05 $(\alpha=5 \%)$ yang menunjukkan Ho ditolak Ha diterima, sehingga hipotesis yang menyatakan "ada pengaruh positif Motivasi Belajar terhadap Hasil Belajar siswa kelas X dan XI TKJ SMK AL FURQON Mranggen Demak" dapat diterima. Sedangkan koefisien determinansi Motivasi Belajar terhadap Hasil Belajar (Y) besarnya adjusted R Square sebesar 0,265 hal ini berarti $26,5 \%$, sedangkan sisanya (100\% $26,5 \%)=73,5 \%$ ) dijelaskan oleh sebab-sebab lain.

Berdasarkan hasil analisis nilai $\mathrm{F}$ sebesar 9,590, sedangkan nilai signifikansi $F$ sebesar 0,000. Dengan menggunakan DFI = 2 dan DF (degree of freedom) sebesar 53 (56 - 2 - 1) di peroleh nilai F sebesar 3,1716 dari hasil tersebut nilai $\mathrm{F}$ hitung lebih besar 9,590 dan nilai signifikansi sebesar 0,000 lebih rendah dari $0,05(\alpha=5 \%)$ yang menunjukkan Ho ditolak dan $\mathrm{Ha}$ diterima, sehingga hipotesis yang menyatakan "ada pengaruh positif penggunaan media pembelajaran cisco (X1) terhadap hasil belajar siswa kelas $X$ dan XI TKJ SMK AL FURQON Mranggen Demak" dapat diterima.

R Square sebesar 0,455. Hasil tersebut menggambarkan sebesar $45,5 \%$ hasil belajar dapat dijelaskan oleh variabel penggunaan media pembelajaran Cisco (X1) dan Motivasi Belajar (X2). Sedangkan sisanya $(100 \%-45,5 \%=64,55)$ dijelaskan oleh sebab-sebab lain.

\section{Saran}

Dari hasil analisis dan pembahasan yang dilakukan, dapat diajukan saran penelitian sebagai berikut :

\section{Guru}

Mengingatkan karakteristik siswa yang bermacam-macam hendaknya guru dapat menentukan metode yang tepat dan dapat mengarahkan, membimbing siswa sehingga prestasi belajar dapat optimal.

\section{Siswa}

Siswa hendaknya mempunyai kebiasaan belajar, motivasi belajar, dan menjaga lingkungan belajar tetap nyaman, bersih sehingga dapat lebih berkonsentrasi dalam belajar sehingga hasil belajar perkaitan komputer yang dicapai oleh siswa lebih baik dari sebelumnya.

\section{Orang tua}

Orang tua sebaiknya selalu memantau dan menyemangati agar motivasi dan hasil belajar anaknya meningkat sehingga prestasi belajar dapat optimal.

\section{Sekolah}

Diharapkan mampu memberikan peningkatan motivasi kepada siswanya agar lebih bersemangat untuk belajar dan tentunya berprestasi, selain itu sekolah merupakan tempat bagi siswa untuk belajar mengembangkan bakat dan kemampuan yang dimiliki. Oleh karena itu sekolah mempunyai kewajiban untuk menyediakan fasilitas belajar yang lengkap, lingkungan yang nyaman, kondusif agar hasil belajar yang dicapai oleh siswa menjadi lebih baik

\section{DAFTAR PUSTAKA}

Abdullah, Ma'ruf, 2015. Metodelogi Penelitian Kuantitatif, Yogyakarta : Aswaja Preesido

Arikunto, Suharsimi .(2010). Dasar-Dasar

Pengaruh Media Pembelajaran Berbasis Cisco IT Essensials Virtual Desktop Dan Motivasi Belajar Dalam Meningkatkan Hasil Belajar Mata Pelajaran Perakitan Komputer Di SMK Al Furqon Mranggen Demak | 133 
Evaluasi Pendidikan. Jakarta : PT Bumi Aksara

Arikunto, Suharsimi . 2009. Prosedur Penelitian. Jakarta :Rineka Cipta

Arsyad, Azhar .(2005). Media Pembelajaran. Jakarta : PT Raja Grafindo Persada

Arsyad, Azhar . 2011. Media Pembelajaran. Jakarta : PT Rajagrafindo Persada

Asmani, Jamal Ma'mur.(2011). Tips Efektif Pemanfaatan Teknologi Informasi dan Komunikasi Dalam Dunia Pendidikan. Jogjakarta : DIVA Press

Daryanto.(2010). Media

Pembelajaran.Yogyakarta. Gava Media

Dimyati dan Mujiyono. 2009. Belajar dan Pembelajaran.Jakarta : Rineka Cipta

Djamarah, Syaiful Bahri dan Aswan Zain. 1997. Strategi Belajar Mengajar. Jakarta : Rineka Cipta

Ghozali, 2005. Metode Penelitian, Jakarta : Gramedia

Hadi, Sutrisno. 1993. Metodologi Research,Yogyakarta : Yayasan Fakultas Psikologi Universitas Gajah Mada

Hamalik, Oemar. 2005. Psikologi Belajar dan Mengajar. Bandung : Sinar Baru Algesindo

Indriana, Dina. 2011. Ragam Alat Bantu Media Pengajaran. Jogjakarta : DIVA Press

Munir. 2008. Multimedia Konsep Dan Aplikasi Dalam Pendidikan. Bandung. Alfabeta

Ismaniati. 2001. Buku Pegangan Sekolah : Pengembangan Program

Pembelajaran Berbasis Komputer.
Yogyakarta : FIP UNY

IT Essentials. 2010 PC Hardware and Software Version 4.0. www.Cisco .com (di unduh 22 April 2018)

Purwanto, M. Ngalim. 1996. Psikologi Pendidikan. Bandung : PT. Remaja Rosdakarya

Purwanto, M. Ngalim. 2009. Psikologi Pendidikan. Bandung : PT. Remaja Rosdakarya

Sadiman, Arif S. 2003. Media Pendidikan Pengertian Pengembangan dan

Pemanfaatan. Jakarta. PT Rajawali Press

Sanjaya, Wina. 2009. Strategi Pembelajaran Berorientasi Standar Proses

Pendidikan. Jakarta : Kencana

Sudjana, Nana.(2005). Penilaian Hasil Proses Belajar Mengajar. Bandung : PT .Remaja Rosdakary

Sudjana, N dan Rivai, A. 2007. Media Pengajaran. Bandung : Sinar Baru Algesindo.

Sugiyono. 2010. Metode Penelitian Pendidikan. Bandung : Alfabeta.

Suyanto, M. 2005. Multimedia Alat Untuk meningkatkan Keunggulan Bersaing. $\mathrm{CV}$. Andi Offset

Slameto. 2003. Belajar dan Faktor-Faktor yang Mempengaruhinya. Jakarta : Rineka Cipta

Sukardi. 2008. Evaluasi Pendidikan Prinsip dan Operasionalnya. Jakarta : Bumi aksara

Sukmadinata, Nana S. 2009. Landasan Psikologi Pendidikan. Bandung: Rosdakarya

Sukmadinata, Nana S. 2009. Metode Penelitian Pendidikan. Bandung : PT

Pengaruh Media Pembelajaran Berbasis Cisco IT Essensials Virtual Desktop Dan Motivasi Belajar Dalam Meningkatkan Hasil Belajar Mata Pelajaran Perakitan Komputer Di SMK Al Furqon Mranggen Demak | 134 
Remaja Rosdakarya.

Suyanto, M .2005. Multimedia Alat Untuk meningkatkan Keunggulan Bersaing.CV. Andi Offset

Syah, Muhibbin. 2012. Psikologi Belajar. Jakarta. PT. Raja Grafindo Persada

Widoyoko, Eko Putro. 2009. Evaluasi Program Pembelajaran. Yogyakarta : Pustaka Pelajar

Winkel, W.S. 1987. Psikologi Pendidikan dan Evaluasi Belajar. Jakarta : P.T
Gramedia

Winkel, W.S. 1991. Psikologi Pengajaran. Jakarta : P.T Gramedia 